\title{
Ischemia Modified Albumin and C-Reactive Protein in Children with $\beta$-Thalassemia Major
}

\author{
Wessam M. Moftah ${ }^{1}$, Ensaf K. Mohammed², Amal A. Morsy³, Asmaa A. Ibrahim² \\ ${ }^{1}$ EL-Minia Insurance Hospital, Cairo, Egypt \\ ${ }^{2}$ Pediatrics Department, Cairo, Egypt \\ ${ }^{3}$ Clinical Pathology Departments, Faculty of Medicine for Girls, Al-Azhar University, Cairo, Egypt \\ Email: ${ }^{\star}$ wessammostafa61@gmail.com, asmaawakeel@yahoo.com
}

How to cite this paper: Moftah, W.M., Mohammed, E.K., Morsy, A.A. and Ibrahim, A.A. (2020) Ischemia Modified Albumin and C-Reactive Protein in Children with $\beta$-Thalassemia Major. Open Journal of Pediatrics, 10, 452-462. https://doi.org/10.4236/ojped.2020.103046

Received: July 24, 2020

Accepted: September 1, 2020

Published: September 4, 2020

Copyright $\odot 2020$ by author(s) and Scientific Research Publishing Inc. This work is licensed under the Creative Commons Attribution International License (CC BY 4.0).

http://creativecommons.org/licenses/by/4.0/

\section{(c) (i) Open Access}

\begin{abstract}
Background: Beta-thalassemia is a hereditary haemoglobinopathy caused by defective hemoglobin $(\mathrm{Hb}) \beta$-globin synthesis, leading to excess $\alpha$-globin chains that cause hemolysis and impair erythropoiesis. Ischemia modified albumin (IMA) is not a signal protein and not generated in pro-inflammatory state alone but rather an end product of oxidative stress. Objectives: The aim of the study was to evaluate ischemia modified albumin (IMA) and C-reactive protein (CRP) in children with $\beta$-thalassemia major and its relation to different iron chelators. Patients and Methods: The study was carried on 40 children diagnosed as beta-thalassemia major recruited from the outpatient clinic and the pediatric department, at Al-Zahraa University Hospital, Faculty of medicine for Girls, Al-Azhar University and EL Minia Insurance Hospital. They were 20 male and 20 female, aged from 4 - 11 years. Another 40 apparently healthy children age and sex matched as control group. CRP and IMA were determined for all participants. Results: There were significant increases in serum CRP, IMA and ferritin levels in patients group compared to control group. There were significant decreases of IMA and CRP levels of thalassemic patients on chelation deferiprone (DFP) compared to deferasirox (DFX) P-value $(<0.01)$ for each. There was a significant positive correlation between serum ferritin and both CRP and IMA levels in thalassemic children $(r=0.40$, $\mathrm{p}<0.01),(\mathrm{r}=0.44, \mathrm{p}<0.01)$ respectively. There was a significant positive correlation between IMA and CRP in beta-thalassemic patients $(\mathrm{r}=0.31, \mathrm{p}=$ 0.02). Conclusion: IMA, CRP and Serum ferritin were higher in children with $\beta$-thalassemia major than controls. Moreover, IMA and CRP levels in thalassemic children on deferiprone (DFP) were significantly lower compared with children on deferasirox (DFX). So it could be considered as useful markers in the follow up assessment of thalassemic patients for early detection of complications.
\end{abstract}




\section{Keywords}

$\beta$-Thalassemia Major, Ischemia Modified Albumin, CRP, Oxidative Stress

\section{Introduction}

Beta thalassemia is due to reduced or absent production of beta globin chains leading to ineffective erythropoiesis, hemolysis and anemia [1]. The most common forms of the disease, $\alpha$ and $\beta$-thalassemia, caused by defective synthesis of the $\alpha$ and $\beta$-globin chains of hemoglobin respectively, they are associated with iron overload resulting from hemolysis and blood transfusions [2].

Chronic blood transfusion therapy caused excessive iron accumulation in different organs which were associated with high early fatalities. With the introduction of iron chelators, especially the oral one during the last decade, rates of survival have improved [3].

Reactive oxygen species (ROS) resulting from conditions such as ischemia, hypoxia, acidosis, free radicals, and free iron can decrease the ability of the $\mathrm{N}$-terminus to bind with transition metals. Human serum albumin with a decreased binding capacity as a result of ischemic events is referred to as ischemia modified albumin (IMA) [4].

C-reactive protein (CRP) is used mainly as a marker of inflammation and infection. Measuring and charting CRP values can prove useful in determining disease progress or the effectiveness or treatments [5].

\section{Aim of the Work}

The aim of the study was to evaluate ischemia modified albumin (IMA) and $\mathrm{C}$-reactive protein (CRP) in children with $\beta$-thalassemia major and its relation to different iron chelators.

\section{Patients and Methods}

The study was carried on 40 children diagnosed as beta-thalassemia major (based on $\mathrm{Hb}$ electrophoresis) on iron chelation therapy during the period from December 2018 to December 2019. They were 20 male and 20 female, aged from 4 - 11 years. Another 40 apparently healthy children ages and sex matched as control group. We excluded Thalassemic children with chronic illness, chronic kidney disease, Hepatitis, Cardio vascular disease, Diabetes mellitus and Obesity. The studied groups were subjected to the followings: Thorough clinical history taking: Included the age of the patient, onset of the disease, the onset and frequency of the blood transfusion, and also chelation therapy (Deferoxamine, Deferasirox, Deferiprone) and age of the start, type and compliance to it and whether splenectomized or not, thorough General and Systemic Examination and Abdominal examination: With emphasis on organomegaly (hepatomegaly or splenomegaly), scar of splenectomy, Through anthropometric measurements. 
All studied groups were subjected to investigations (CBC, ALT, AST, Urea, Creatinine, serum ferritin, CRP, IMA) which were determined for all participants.

\subsection{Collection of Blood Samples}

From each child in this study $(5 \mathrm{ml})$ of venous blood was withdrawn in all groups, under complete aseptic condition before their regular blood transfusion for the group I and divided into two tubes: 1st tube containing EDTA for complete blood picture $(\mathrm{CBC})$ that were done immediately and 2nd plane tube was left in the incubator for 30 minutes, centrifuged at 3000 r. P.m. for 10 minutes and then separated serum was collected and divided into two Eppendorf: 1st one for routine laboratory investigations (Liver, kidney function tests and CRP) and the other was stored at -20 for IMA assays. (IMA) was done on (ELISA Kits purchased from Glory Science Company, Ltd., USA), C-reactive protein (CRP) was done on (AVITEX, CPR, Omega Diagnostics Ltd, Scotland, United Kingdom).

\subsection{Statistical Analysis}

Data were collected, revised, coded, and entered into the statistical package for social science (IBM SPSS), version 22. Spearman's correlation coefficients were used to assess the relation between two studied parameters in the same group. The receiver operating a characteristic curve was used to assess the best cutoff point with sensitivity and specificity. The p-value was considered significant as the following: $(\mathrm{P}>0.05$ : Non significant, $\mathrm{P}<0.05$ : Significant and $\mathrm{P}<0.01$ : Highly significant).

\subsection{Ethical Considerations}

Approval of the study from the faculty of medicine, Al-Azhar and minia University ethics committee will be obtained.

An informed consent will be taken from the participant's caregivers.

\section{Results}

The general demographic and laboratory data of patients and controls. Z-score for weight, height, BMI and hemoglobin level in thalassemic children were significantly lower in patients than in controls Moreover, there was a significant increase in serum ferritin, CRP and (IMA) in children with beta-thalassemia than in controls (Table 1 ).

There was three (7.5\%) thalassemic patients had done splenectomy (Table 2).

There was significant increase in CRP and IMA in Patients who underwent splenectomy (Table 3).

The thalassemic patients on deferiprone (DFP) chelation had significantly lower level of CRP compared to deferasirox (DFX). Also, Concerning IMA, thalassemic patients on DFP chelation had the lowest level followed by DFX (Table 4). 
Table 1. Comparison of demographic and laboratory data between children with beta thalassemia major and controls.

\begin{tabular}{|c|c|c|c|}
\hline \multirow[b]{2}{*}{ Variable } & \multicolumn{2}{|c|}{ Groups } & \multirow{2}{*}{$\begin{array}{l}\text { P-value } \\
\text { (Sig.) }\end{array}$} \\
\hline & $\begin{array}{c}\text { Group (I) } \\
\text { Patients }(n=40)\end{array}$ & $\begin{array}{c}\text { Group (II) } \\
\text { Control }(\mathrm{n}=40)\end{array}$ & \\
\hline Age (year) & $\begin{array}{c}7.3 \pm 2.4 \\
(4-11)\end{array}$ & $\begin{array}{c}7.5 \pm 2.2 \\
(4-11)\end{array}$ & $0.74^{\mathrm{NS}}$ \\
\hline \multirow[b]{2}{*}{ Female } & $21(52.5 \%)$ & $21(52.5 \%)$ & \\
\hline & $19(47.5 \%)$ & $19(47.5 \%)$ & $1.0^{\mathrm{NS}}$ \\
\hline Weight (kg) & $\begin{array}{c}16.9 \pm 4.0 \\
(11-23)\end{array}$ & $\begin{array}{c}23.5 \pm 5.3 \\
(15-35)\end{array}$ & $<0.01^{* *}$ \\
\hline Height $(\mathrm{cm})$ & $\begin{array}{c}104.1 \pm 12.2 \\
(86-129)\end{array}$ & $\begin{array}{c}118.8 \pm 12.7 \\
(100-145)\end{array}$ & $<0.01^{* *}$ \\
\hline Body mass index $\left(\mathrm{kg} / \mathrm{m}^{2}\right)$ & $\begin{array}{c}15.4 \pm 1.22 \\
(13.5-17.7)\end{array}$ & $\begin{array}{c}16.4 \pm 0.68 \\
(15.0-17.8)\end{array}$ & $<0.01^{* *}$ \\
\hline Z-score & $\begin{array}{l}-0.39 \pm 0.96 \\
(-2.50-1.10)\end{array}$ & $\begin{array}{c}0.28 \pm 0.52 \\
(-0.80-1.30)\end{array}$ & $<0.01^{* *}$ \\
\hline Hemoglobin (g/dl) & $\begin{array}{c}6.65 \pm 1.13 \\
(3.70-9.30)\end{array}$ & $\begin{array}{c}11.84 \pm 1.86 \\
(8.40-15.60)\end{array}$ & $<0.01^{* *}$ \\
\hline $\operatorname{TLC}\left(10^{9} / \mathrm{L}\right)$ & $\begin{array}{l}8.98 \pm 4.05 \\
(2.0-20.0)\end{array}$ & $\begin{array}{c}9.04 \pm 3.98 \\
(3.50-18.6)\end{array}$ & $0.95^{\mathrm{NS}}$ \\
\hline Platelets $\left(10^{3} / \mu \mathrm{l}\right)$ & $\begin{array}{c}320.7 \pm 130.1 \\
(91-793)\end{array}$ & $\begin{array}{c}289.1 \pm 98.6 \\
(106-504)\end{array}$ & $0.23^{\mathrm{NS}}$ \\
\hline $\operatorname{ALT}(\mathrm{U} / \mathrm{ml})$ & $\begin{array}{c}26.8 \pm 18.1 \\
(10-81)\end{array}$ & $\begin{array}{c}23.6 \pm 11.8 \\
(7-59)\end{array}$ & $0.36^{\mathrm{NS}}$ \\
\hline $\operatorname{AST}(\mathrm{U} / \mathrm{ml})$ & $\begin{array}{c}34.8 \pm 13.7 \\
(14-84)\end{array}$ & $\begin{array}{c}32.8 \pm 16.2 \\
(11-95)\end{array}$ & $0.56^{\mathrm{NS}}$ \\
\hline Blood Urea (mg/dl) & $\begin{array}{c}25.7 \pm 9.6 \\
(13-72)\end{array}$ & $\begin{array}{c}27.8 \pm 15.1 \\
(9-79)\end{array}$ & $0.45^{\mathrm{NS}}$ \\
\hline S.Createnine $(\mathrm{mg} / \mathrm{dl})$ & $\begin{array}{c}0.34 \pm 0.09 \\
(0.16-0.60)\end{array}$ & $\begin{array}{c}0.37 \pm 0.18 \\
(0.10-0.80)\end{array}$ & $0.29^{\mathrm{NS}}$ \\
\hline S. ferritin (ng/ml) & $\begin{array}{c}1215.3 \pm 540.1 \\
(327-2436)\end{array}$ & $\begin{array}{c}7.9 \pm 4.8 \\
(3-48)\end{array}$ & $<0.01^{\star *}$ \\
\hline C-reactive protein $(\mathrm{mg} / \mathrm{L})$ & $\begin{array}{l}5.81 \pm 5.06 \\
(0.1-48.0)\end{array}$ & $\begin{array}{l}1.01 \pm 0.87 \\
(0.1-6.50)\end{array}$ & $<0.01^{\star *}$ \\
\hline Ischemia modified albumin (ng/ml) & $\begin{array}{c}86.5 \pm 13.5 \\
(63.9-111.8)\end{array}$ & $\begin{array}{c}3.75 \pm 1.35 \\
(2.01-8.68)\end{array}$ & $<0.01^{\star *}$ \\
\hline
\end{tabular}

${ }^{* *}$ Highly significant $(\mathrm{p}<0.01) ;{ }^{*}$ Significant $(\mathrm{p}<0.05)$. 
Table 2. Percentage of splenectomy among thalassemic patients.

\begin{tabular}{|c|c|c|}
\hline \multicolumn{2}{|c|}{ Variable } & \multirow{2}{*}{$\begin{array}{c}\text { Patients group }(\mathrm{n}=40) \\
37(92.5 \%)\end{array}$} \\
\hline & No & \\
\hline Spelenectomy & Yes & $3(7.5 \%)$ \\
\hline
\end{tabular}

Table 3. CRP and IMA in cases with splenectomy and other without splenectomy in the patients group.

\begin{tabular}{cccc}
\hline & \multicolumn{2}{c}{ Groups } \\
\cline { 2 - 3 } Variable & $\begin{array}{c}\text { Patients with } \\
\text { spelenctomy } \\
(\mathrm{n}=3)\end{array}$ & $\begin{array}{c}\text { Patients without } \\
\text { spelenectomy } \\
(\mathrm{n}=37)\end{array}$ & P-value (Sig.) \\
\hline C-reactive protein $(\mathrm{mg} / \mathrm{L})$ & $19.17 \pm 25.0$ & $4.70 \pm 6.07$ & $<0.01^{* *}$ \\
Ischemia modified albumin $(\mathrm{ng} / \mathrm{ml})$ & $97.5 \pm 8.5$ & $85.6 \pm 8.3$ & $0.02^{*}$
\end{tabular}

${ }^{* *}$ Highly significant $(\mathrm{p}<0.01)$; ${ }^{*}$ Significant $(\mathrm{p}<0.05)$.

Table 4. CRP and Ischemia modified albumin in relation to types of chelators.

\begin{tabular}{cccc}
\hline & \multicolumn{2}{c}{$\begin{array}{c}\text { Group }(1) \\
\text { Patients }(\mathrm{n}=40)\end{array}$} & \multirow{2}{c}{ P-value (Sig.) } \\
\cline { 2 - 3 } Variable & $\begin{array}{c}\text { On Deferiprone } \\
(\mathrm{DFP})(\mathrm{n}=15)\end{array}$ & $\begin{array}{c}\text { On deferasirox } \\
(\mathrm{DFX})(\mathrm{n}=25)\end{array}$ & \\
\hline C-reactive protein $(\mathrm{mg} / \mathrm{L})$ & $3.04 \pm 2.16$ & $7.55 \pm 6.1$ & $<0.01^{* *}$ \\
Ischemia modified albumin $(\mathrm{ng} / \mathrm{ml})$ & $74.8 \pm 5.8$ & $93.5 \pm 11.8$ & $<0.01^{* *}$ \\
\hline
\end{tabular}

Our results also, show that there was a significant positive correlation between IMA and $\mathrm{S}$. ferritin $(\mathrm{r}=0.44, \mathrm{p}<0.01)$ (Figure 1$)$. There was a significant positive correlation between CRP and S. ferritin $(r=0.40, p<0.01)$ (Figure 2). There were significant positive correlations between IMA and CRP in beta-thalassemic patients $(\mathrm{r}=0.31, \mathrm{p}=0.02)$ (Figure 3).

The results of the ROC curve analysis revealed that IMA cutoff was $>36.1$ $(\mathrm{ng} / \mathrm{ml})$ and CRP cutoff was $>0.66(\mathrm{mg} / \mathrm{L})$. So it could be considered as useful markers in the follow up assessment of thalassemic patients for early detection of complications (Figure 4 and Table 5).

\section{Discussion}

In our study, there was a significant decrease in weight, height, BMI, Z-score in thalassemic children compared with controls. These findings were in agreement with a study performed by Elalfy et al. [6] who found that the patients reported significantly lower growth parameters (weight, height and BMI). Vogiatzi et al. [7] reported that growth failure is multifactorial in thalassemia, related to chronic hypoxia due to chronic anemia, chelation toxicity, low serum zinc level, hepatic iron overload with hepatic dysfunction and iron associated endocrinopathies such as hypogonadism, hypothyroidism and growth hormone deficiency. 


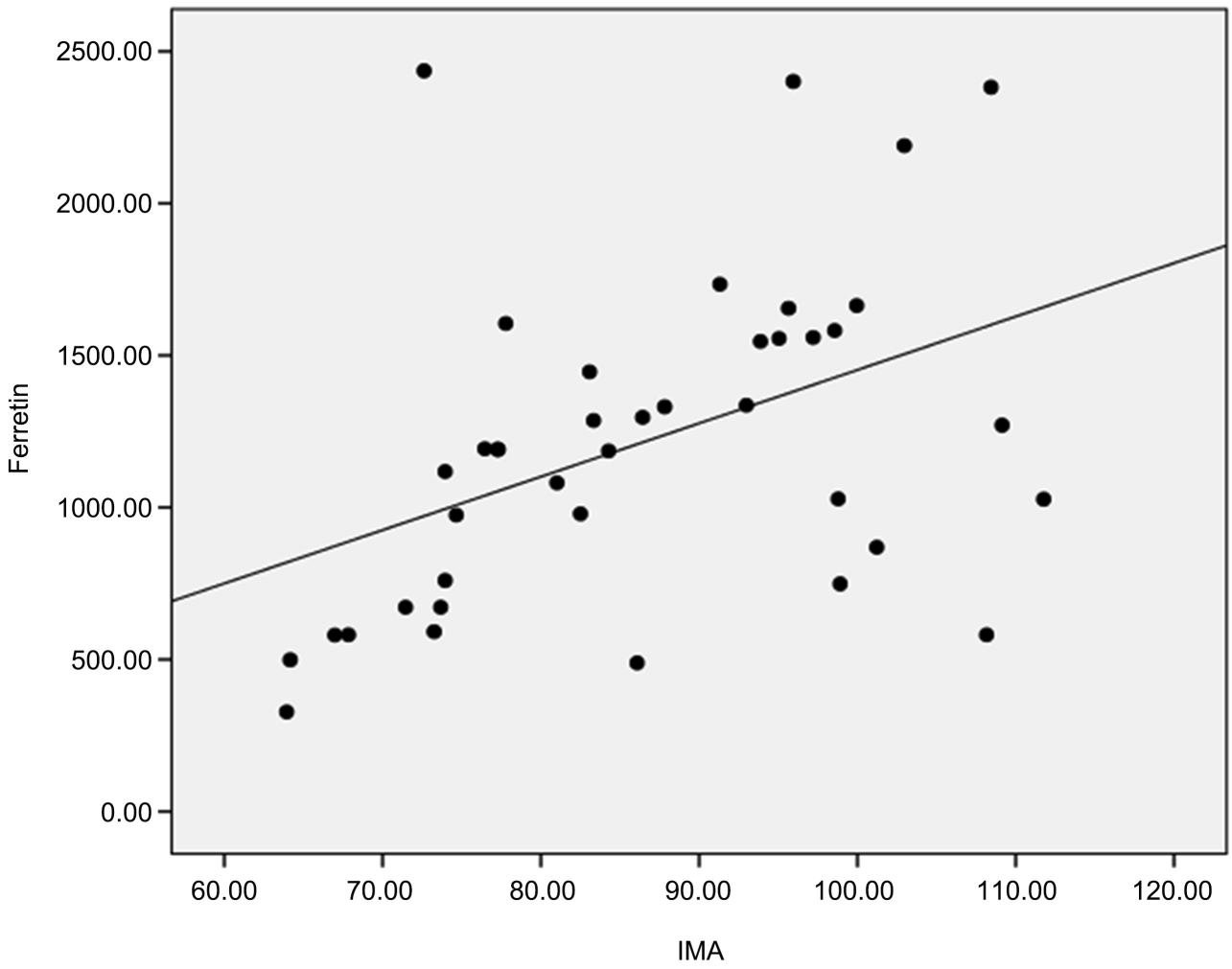

Figure 1. Correlation between serum ferritin and IMA levels in children with beta thalassemia major $(\mathrm{r}=0.44, \mathrm{p}<0.01)$.

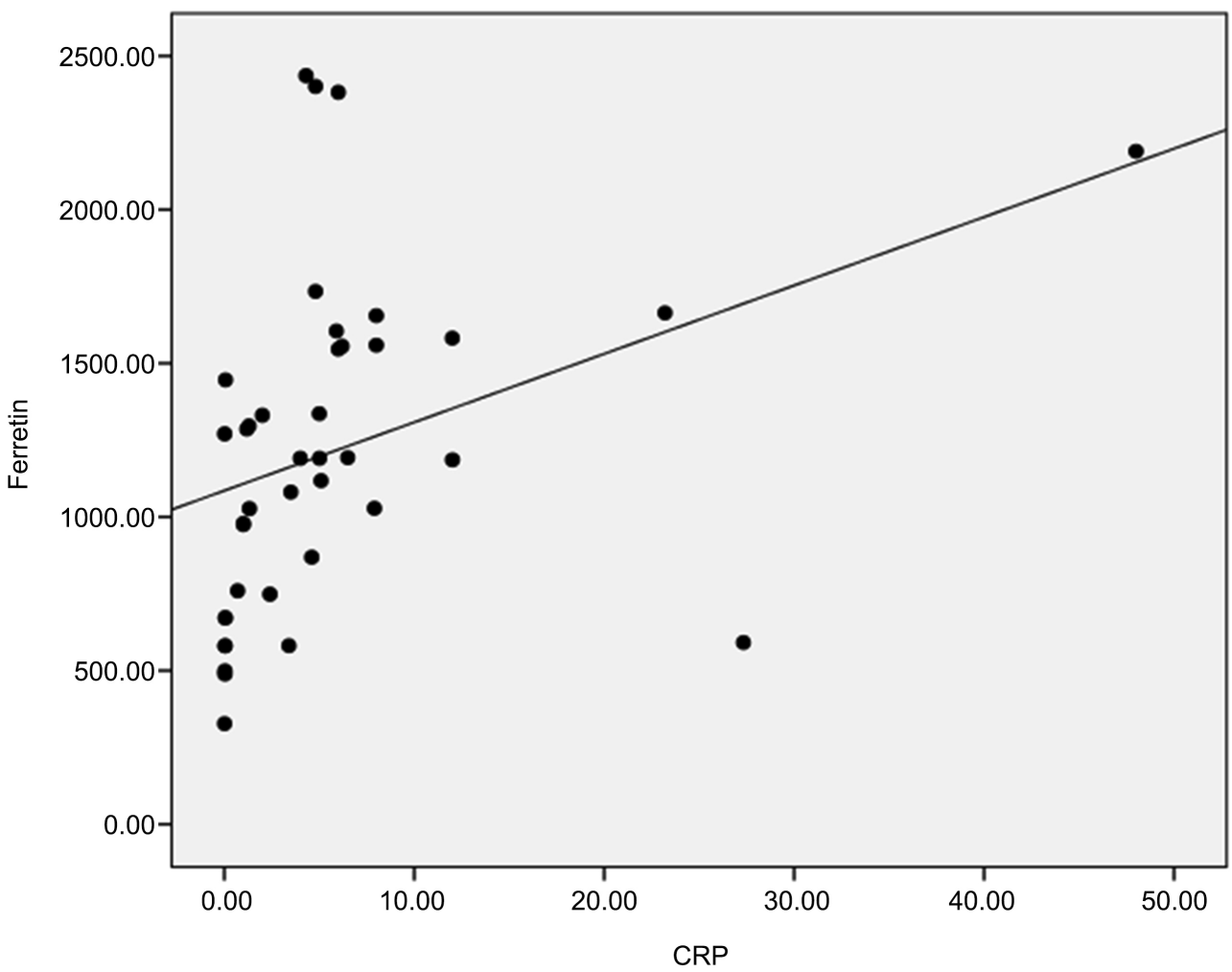

Figure 2. Correlation between serum ferritin and CRP levels in children with beta thalassemia major $(\mathrm{r}=0.40, \mathrm{p}<0.01)$. 


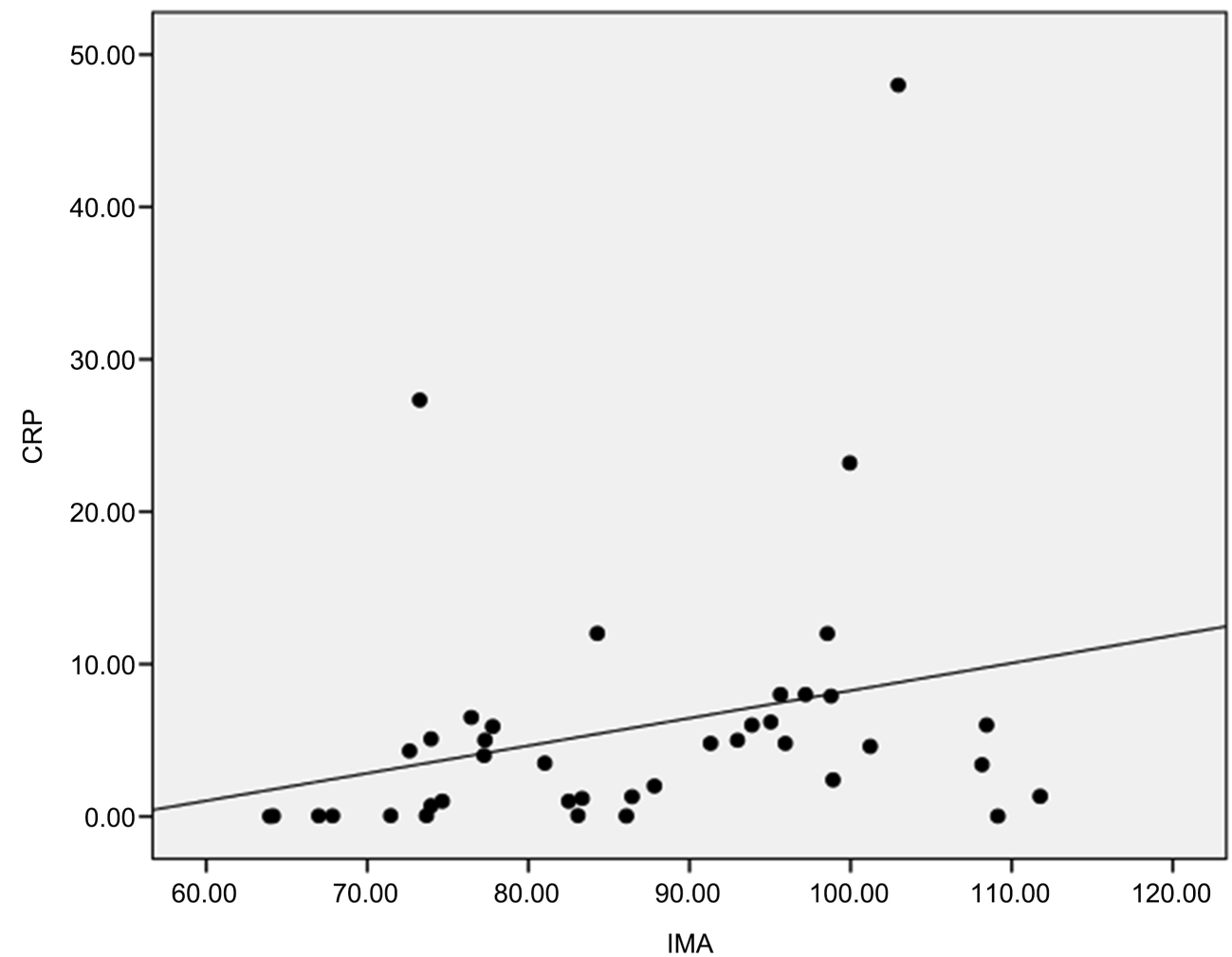

Figure 3. Correlation between CRP and IMA levels in children with beta thalassemia major $(\mathrm{r}=$ $0.31, \mathrm{p}=0.02)$.

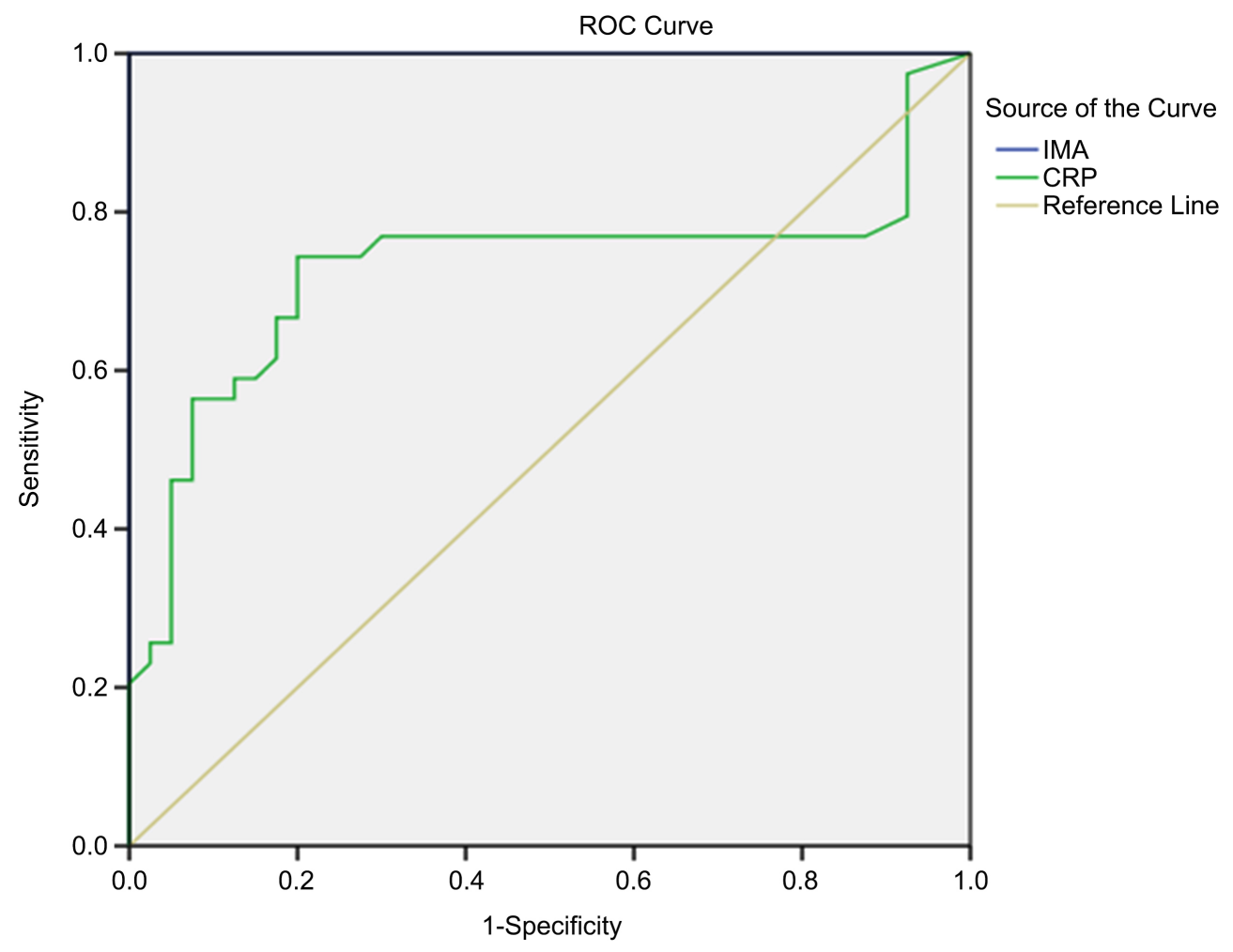

Diagonal segments are produced by ties

Figure 4. ROC curve of CRP and IMA in prediction of beta-thalassemia. 
Table 5. ROC curve analysis of IMA and CRP in prediction of beta-thalassemia major.

\begin{tabular}{|c|c|c|c|c|c|c|c|}
\hline Parameter & AUC & Cutoff & Sensitivity (\%) & Specificity (\%) & PPV (\%) & NPV (\%) & Diagn. Accuracy (\%) \\
\hline CRP (mg/L) & 0.73 & $>0.66$ & 77.5 & 72.2 & 73.8 & 76.3 & 75.0 \\
\hline IMA (ng/ml) & 1.0 & $>36.1$ & 100 & 100 & 100 & 100 & 100 \\
\hline
\end{tabular}

The present study revealed a too high increase in serum ferritin level in beta-thalassemia group in comparison with control one. These results were in agreement with Sherief et al. [8] who found significantly higher serum ferritin levels in thalassemia patients when compared to controls. Olivieri and Brittenham [9] found that high serum ferritin is a predictable consequence of continuous blood transfusion in thalassemic patients, though it may also increase during acute inflammation, it remains the most common indicator of iron overload in thalassemic patients.

The present results demonstrate that CRP and IMA Were significantly elevated in beta-thalassemia group compared to control one. Our finding (CRP) was in agreement with; Abduljabbar et al. [10] who found a significant elevation in serum CRP level in thalassemic children compared to normal controls. Arinzon et al. [11] reported that C-reactive protein levels rise rapidly in response to infection or tissue inflammation. Overall, many studies reported that CRP was useful in thalassemia and has been shown to be positively associated with the risk of kidney and cardiovascular disease [12].

In the present study regarding the IMA was in agreement with Mousa et al. [13] who found that IMA was significantly increased in thalassemic children compared with the control group. They attributed the increased level of IMA in thalassemic patients that it may be due to iron-induced oxidative stress and hence it's potential significance as a new marker of oxidative stress in such patients.

Anemia may contribute to the rise in IMA as it causes mild hypoxia due to low hemoglobin levels, altering the metal-albumin binding and in addition, the reduction in hemoglobin levels could change the tissue oxygen delivery, resulting in hemoglobin-induced variations in arterial $\mathrm{O}_{2}$ content [14].

Odaman et al. [15] reported that iron-driven oxidative stresses in association with chronic anemia and hypoxia are the most likely causes that lead to the modification of the $\mathrm{N}$-terminus of serum albumin and thus the formation of increased levels of IMA in $\beta$-thalassemia patients.

In the present study, there was three (7.5\%) thalassemic patients had done splenectomy. Patients who underwent splenectomy had significantly higher level of CRP and IMA. Our results were in agreement with; Adly et al. [16] who reported that thalassemic patients who had splenectomy had significantly higher level of IMA and CRP. Also, they reported that elevation was strongly associated with vascular inflammation, liver dysfunction, hypoxemia, iron overload, left ventricular dysfunction, and increased cardiac output. 
The present study demonstrated that thalassemic patients on deferiprone (DFP) chelator had significantly lower level of CRP and IMA compared to deferasirox (DFX) chelator. This can be attributed to the fact that DFP chelates the excess of iron, reducing the circulating and intracellular free iron that leads to decreased formation of ROS [17].

Our study illustrated that there was a significant positive correlation between IMA and S. ferritin. Also, there was a significant positive correlation between CRP and ferritin. Also, there was a significant positive correlation between IMA and CRP in beta-thalassemia patients group. However, there was no significant correlation between IMA level and Hb, TLC, platelets, ALT, AST, urea and createnine in thalassemic patients. Also, our study illustrated that there was no significant correlation between CRP level and $\mathrm{Hb}$, platelets, ALT, AST, urea and createnine in thalassemic patients.

Our results were in agreement with El-Setohy [18] who found that there was a significant positive correlation between serum ferritin and both CRP and IMA levels in thalassemic children. Also, there was a significant positive correlation between IMA and CRP levels in thalassemic children.

The present study revealed that IMA cutoff was $>36.1(\mathrm{ng} / \mathrm{ml})$ and CRP cutoff was $>0.66(\mathrm{mg} / \mathrm{L})$. So it could be considered as useful markers in the follow up assessment of thalassemic patients for early detection of complications.

\section{Conclusions}

- The present study revealed that ischemia modified albumin (IMA), C-reactive protein (CRP) and Serum ferritin were a significant increase in children with $\beta$-thalassemia major than controls. So it could be considered as useful markers in the follow up assessment of thalassemic patients for early detection of complications.

- Children on DFP significantly had lower IMA levels and CRP compared with children on DFX reflecting the rationale to support iron chelation therapy for the elimination of the free iron species.

\section{Recommendations}

- According to our study, we can recommend anti-oxidants administrations with the management of thalassemic patients that could improve the prognosis.

- CRP and S. ferritin can serve as good indicators for the future risks which the thalassemic patients may face causing more complicated damages ranging from splenomegaly to heart failure.

- More studies are needed to further investigate the effect of DFP on inflammation in thalassemic children.

\section{Conflicts of Interest}

The authors declare no conflicts of interest regarding the publication of this paper. 


\section{References}

[1] Al-Mosawy, W.F. (2017) The Beta-Thalassemia. Scientific Journal of Medical Research, 1, 24-30. https://doi.org/10.37623/SJMR.2017.1105

[2] Hanafi, H., Sadeghnia, H., Zoljalali, N., et al. (2017) Effect of Mesoporous Silica Nanoparticles on Cell Viability and Markers of Oxidative Stress. Toxicology Mechanisms and Methods, 25, 433-439.

[3] Christina, N.K. and George, J.K. (2016) Efficacy and Safety of Iron-Chelation Therapy with Deferoxamine, Deferiprone, and Deferasirox for the Treatment of Iron-Loaded Patients with Non-Transfusion-Dependent Thalassemia Syndromes. Drug Design, Development and Therapy, 10, 465-481.

[4] Awadallah, S., Atoum, M., Nimer, N. and Saleh, S. (2012) Ischemia Modified Albumin: An Oxidative Stress Marker in $\beta$-Thalassemia Major. Clinica Chimica Acta, 10, 1016-1037. https://doi.org/10.1016/j.cca.2012.01.037

[5] Jain, S., Gautam, V. and Naseem. S. (2011) Acute-Phase Proteins: As Diagnostic Tool. Journal of Pharmacy \& Bioallied Sciences, 3, 118-127. https://doi.org/10.4103/0975-7406.76489

[6] Elalfy, M.S., Farid, M.N., Labib, J.H. and RezkAllah, H.K. (2014) Quality of Life of Egyptian B-Thalassemia Major Children and Adolescents. The Egyptian Journal of Haematology, 39, 222-226. https://doi.org/10.4103/1110-1067.153963

[7] Vogiatzi, M.G., Macklin, E.A., Trachtenberg, F.L., et al. (2009) Differences in the Prevalence of Growth, Endocrine and Vitamin D Abnormalities among the Various Thalassemia Syndromes in North America. British Journal of Haematology, 146, 546-556. https://doi.org/10.1111/j.1365-2141.2009.07793.x

[8] Sherief, L.M., Dawood, O., Ali, A., Sherbiny, H.S., et al. (2017) Premature Atherosclerosis in Children with Beta-Thalassemia Major: New Diagnostic Marker. BMC Pediatrics, 17, Article No. 69. https://doi.org/10.1186/s12887-017-0820-1

[9] Olivieri, N.F. and Brittenham, G.M. (1997) Iron-Chelating Therapy and the Treatment of Thalassemia. Blood, 89, 739-761. https://doi.org/10.1182/blood.V89.3.739

[10] Abduljabbar A.A. and Mehmetçik, G. (2019) Estimation of MDA, CRP and Some Hematological Parameters in the Mature Cypriot Thalassemia Patients. ZANCO Journal of Pure and Applied Sciences, 31, 143-149. https://doi.org/10.21271/zjpas.31.s4.23

[11] Arinzon, Z., Peisakh, A., Schrire, S. and Berner, Y. (2011) C-Reactive Protein (CRP) an Important Diagnostic and Prognostic Tool in Nursinghome-Associated Pneumonia. Archives of Gerontology and Geriatrics, 53, 364-369. https://doi.org/10.1016/j.archger.2011.01.006

[12] Rifkin, D.E., Katz, R., Fried, L.F., et al. (2010) Association between Baseline Kidney Functions and Change in CRP: An Analysis of the Cardiovascular Health Study. Nephron Clinical Practice, 115, c114-c121. https://doi.org/10.1159/000312874

[13] Mousa, S., Afifi, M., Saedii, A., et al. (2016) Ischemia Modified Albumin in Children with Transfusion-Dependent $\beta$-Thalassemia: A New Marker for an Old Problem. The Egyptian Journal of Haematology, 41, 45-49. https://doi.org/10.4103/1110-1067.186397

[14] Roach, R., Koskolou, M., Calbet, J. and Saltin, B. (1999) Arterial $\mathrm{O}_{2}$ Content and Tension in Regulation of Cardiac Output and Leg Blood Flow during Exercise in Humans. American Journal of Physiology, 276, H438-H445. https://doi.org/10.1152/ajpheart.1999.276.2.H438

[15] Odaman Al., I., Ayçiçek, A., Ersoy, G., Bayram, C., Neşelioğlu, S. and Erel, Ö. 
(2019) Thiol Disulfide Homeostasis and Ischemia-Modified Albumin Level in Children with Beta-Thalassemia. Journal of Pediatric Hematology/Oncology, 41, e463-e466.

[16] Adly, A., ElSherif, N., Ismail, E., Ibrahim, Y.A., Niazi, G. and Elmetwally, S.H. (2017) Ischemia-Modified Albumin as a Marker of Vascular Dysfunction and Subclinical Atherosclerosis in $\beta$-Thalassemia Major. Redox Report, 22, 430-438. https://doi.org/10.1080/13510002.2017.1301624

[17] Pilo, F., Di Tucci, A., Dessì, L. and Angelucci, E. (2009) Management of Transfusional Chronic Iron Overload: Focus on Deferasirox. Clinical Medicine and Therapeutics, 1, 735-745. https://doi.org/10.4137/CMT.S1970

[18] El-Setohy (2014) Ischemia Modified Albumin and C-Reactive Protein in B-Thalassemic Children and Its Relation to Iron Chelation Thereby. M.Sc. Thesis, Minia University, Minia. 